\title{
Whole genome sequencing for diagnosis of neurological repeat
}

\section{expansion disorders.}

Kristina Ibanez $\mathrm{PhD}^{1,2}$, James Polke $\mathrm{PhD}^{* 3}$, Tanner Hagelstrom $\mathrm{PhD}^{* 4}$, Egor Dolzhenko $\mathrm{PhD}^{4}$, Dorota Pasko PhD ${ }^{1}$, Ellen Thomas MRCPC PhD ${ }^{1}$, Louise Daugherty ${ }^{1,5}$, Dalia Kasperaviciute PhD ${ }^{1,2}$, Ellen $\mathrm{M}$ McDonagh $\mathrm{PhD}^{1,6}$, Katherine $\mathrm{R}$ Smith $\mathrm{PhD}^{1}$, Antonio Rueda Martin ${ }^{1}$, Dimitris Polychronopoulos $\mathrm{PhD}^{1}$, Heather Angus-Leppan MBBS (Hons) MSc MD FRACP FRCP ${ }^{7,8}$, Kailash P Bhatia $\mathrm{MD}^{9}$, James $\mathrm{E}$ Davison $\mathrm{PhD}^{10}$, Richard Festenstein $\mathrm{MB}$ BS FRCP $\mathrm{PhD}^{11,12}$, Pietro Fratta MD $\mathrm{PhD}^{13}$, Paola Giunti MD ${ }^{14,9}$, Robin Howard $\mathrm{PhD}^{14}$, Laxmi Venkata Prasad Korlipara MBBS FRCP PhD ${ }^{15}$, Matilde Laurá MD PhD ${ }^{16}$, Meriel McEntagart $\mathrm{MD}^{17}$, Lara Menzies $\mathrm{PhD}^{18}$, Huw Morris MD ${ }^{19,20}$, Mary $M$ Reilly $M D^{14,16}$, Robert Robinson $\mathrm{PhD}^{21}$, Elisabeth Rosser $\mathrm{MD}^{18}$, Francesca Faravelli ${ }^{18}$, Anette Schrag $\mathrm{MD}^{22}$, Jonathan M Schott $\mathrm{MD}^{23}$, Thomas T Warner FRCP PhD ${ }^{9,24,25}$, Nicholas W Wood MD ${ }^{9,14}$, David Bourn ${ }^{26}$, Kelly Eggleton ${ }^{3}$, Robyn Labrum ${ }^{3}$, Philip Twiss ${ }^{27}$, Stephen Abbs $^{27}$, Liana Santos ${ }^{3}$, Ghareesa Almheiri ${ }^{13}$, Isabella Sheikh ${ }^{13}$, Jana Vandrovcova PhD ${ }^{13}$, Christine Patch ${ }^{1}$, Ana Lisa Taylor Tavares $\mathrm{MD}^{1}$, Zerin Hyder $\mathrm{MD}^{1}$, Anna Need $\mathrm{PhD}^{1}$, Helen Brittain $\mathrm{MD}^{1}$, Emma Baple MBBS, PhD ${ }^{1,28,29}$, Loukas Moutsianas $\mathrm{PhD}^{1,2}$, Genomics England Research Consortium ${ }^{30}$, Viraj Deshpande $\mathrm{PhD}^{4}$, Denise L Perry MS ${ }^{4}$, Shankar Ajay PhD , Aditi Chawla $\mathrm{PhD}^{4}$, Vani Rajan $\mathrm{MS}^{4}$, Kathryn Oprych $\mathrm{MD}^{31,32}$, Patrick F Chinnery FRCP ${ }^{33}$, Angela Douglas PhD FRCPath $^{34}$, Gill Wilson FRCP ${ }^{35}$, Sian Ellard PhD FRCPath ${ }^{36}$, Karen Temple PhD FRCP ${ }^{37,38}$, Andrew Mumford PhD FRCP ${ }^{39}$, Dom McMullan ${ }^{40}$, Kikkeri Naresh ${ }^{41}$, Frances Flinter MD ${ }^{42}$, Jenny C Taylor $\mathrm{PhD}^{43}$, Lynn Greenhalgh FRCP ${ }^{34}$, William Newman MD PhD ${ }^{44}$, Paul Brennan FRCP ${ }^{45}$, John A. Sayer 
FRCP PhD ${ }^{46,47,48}$, F Lucy Raymond MD ${ }^{49,50}$, Lyn S Chitty PhD MRCOG ${ }^{31,32}$, Zandra C Deans ${ }^{51}$, Sue Hill FMedSci ${ }^{52}$, Tom Fowler FFPH PhD MPH ${ }^{1,2}$, Richard Scott MRCPCH PhD ${ }^{1}$, Henry Houlden MD PhD ${ }^{3,13}$, Augusto Rendon PhD ${ }^{1}$, Mark J Caulfield FRCP FMedSci $\dagger^{1,2}$, Michael A Eberle PhD† ${ }^{\# 4}$, Ryan J Taft PhD† ${ }^{\# 4}$, Arianna Tucci MD PhD $\dagger^{2,1}$

${ }^{1}$ Genomics England, Queen Mary University of London, Charterhouse Square, London, EC1M, UK, ${ }^{2}$ William Harvey Research Institute, Queen Mary University of London, London, EC1M 6BQ, UK, ${ }^{3}$ Neurogenetics Unit, National Hospital for Neurology and Neurosurgery, London, UK, ${ }^{4}$ Illumina, Inc, 5200 Illumina Way, San Diego, California, 92122, USA, ${ }^{5}$ Healx Ltd., Charter House, 66-68 Hills Rd, Cambridge, CB2 1LA, UK, ${ }^{6}$ Open Targets and European Molecular Biology Laboratory - European Bioinformatics Institute (EMBL-EBI), Wellcome Genome Campus, Hinxton, CB10 1SD, UK, ${ }^{7}$ Royal Free London NHS Foundation Trust, London, UK, ${ }^{8}$ UCL Queen Square Institute of Neurology London, London, UK, ${ }^{9}$ Department of Movement and Clinical Neuroscience, UCL Queen Square Institute of Neurology, University College London, London, UK, ${ }^{10}$ Metabolic Medicine, Great Ormond Street Hospital for Children NHS Foundation Trust, London, UK, ${ }^{11}$ Gene Control Mechanisms and Disease Group, Faculty of Medicine, Department of Brain Sciences and MRC, London, UK, ${ }^{12}$ Institute for Medical Sciences, Imperial College London, Hammersmith Hospital, London, UK, ${ }^{13}$ Department of Neuromuscular Diseases, Institute of Neurology, University College London, London, UK, ${ }^{14}$ National Hospital for Neurology and Neurosurgery, University College London Hospitals NHS trust, London, UK, ${ }^{15} \mathrm{UCL}$ Movement Disorders Centre, Institute of Neurology, London, UK, ${ }^{16}$ Department of 
Neuromuscular Diseases, UCL Queen Square Institute of Neurology, London, UK, ${ }^{17}$ St George's, University of London, London, UK, ${ }^{18}$ Department of Clinical Genetics, Great Ormond Street Hospital for Children NHS Foundation Trust, London, UK, ${ }^{19}$ Department of Movement and Clinical Neuroscience, UCL Queen Square Institute of Neurology, University College London, London, WC1N 3BG, UK, ${ }^{20}$ UCL Movement Disorders Centre, UCL Queen Square Institute of Neurology, London, WC1N 3BG, UK, ${ }^{21}$ Great Ormond Street Hospital for Children National Health Service Trust, London, UK, ${ }^{22}$ Department of Movement and Clinical Neuroscience, UCL Queen Square Institute of Neurology, University College London, London, WCN 3BG, UK, ${ }^{23}$ Dementia Research Centre, UCL Queen Square Institute of Neurology, University College London, London, WCN 3BG, UK, ${ }^{24}$ Queen Square Brain Bank for Neurological Disorders, UCL Queen Square Institute of Neurology, London, UK, ${ }^{25}$ Reta Lila Weston Institute of Neurological Studies, UCL Queen Square Institute of Neurology, London, UK, ${ }^{26}$ Northern Genetics Service, Institute of Genetic Medicine, Central Parkway, Newcastle Upon Tyne, UK, ${ }^{27}$ East Midlands and East of England NHS Genomic Laboratory Hub, Addenbrooke's Treatment Centre, Cambridge, UK, ${ }^{28}$ University of Exeter Medical School, Exeter, EX2 5DW, UK, ${ }^{29}$ Peninsula Clinical Genetics Service, Royal Devon \& Exeter Hospital (Heavitree), Gladstone Road, Exeter, EX1 2ED, UK, ${ }^{30}$ Genomics England, Queen Mary University of London, London, EC1M, UK, ${ }^{31}$ Great Ormond Street Hospital for Children NHS Foundation Trust, London, UK, ${ }^{32}$ UCL GOS Institute of Child Health, London, UK, ${ }^{33} \mathrm{MRC}$ Mitochondrial Biology Unit \& Department of Clinical Neurosciences, University of Cambridge, Cambridge Biomedical Campus, Cambridge, UK, ${ }^{34}$ Liverpool Women's NHS Foundation Trust., Crown street, Liverpool, L8 7SS, UK, ${ }^{35}$ Sheffield Children's Hospital Clarkson St, Broomhall, Sheffiel, S10 2TH, UK, ${ }^{36}$ University of Exeter Medical School, Royal 
Devon and Exeter Hospital, Wonford, Barrack Road, Exeter, EX2 5DW, UK, ${ }^{37}$ University of Southampton, University Road, Southampton, SO17 1BJ, UK, ${ }^{38}$ Southampton General Hospital, Tremona Road, Southampton, SO16 6YD, UK, ${ }^{39}$ School of Cellular and Molecular Medicine, University of Bristol, Bristol, UK, ${ }^{40}$ Birmingham Women's Hospital, Mindelsohn Way, Edgbaston, Birmingham, B15 2TG, UK, ${ }^{41}$ Imperial College Healthcare NHS Trust Hammersmith Hospital, Du Cane Road, London, W12 0HS, UK, ${ }^{42}$ Clinical Genetics Department, Guy's \& St Thomas' NHS Foundation Trust, London, SE1 9RT, UK, ${ }^{43}$ NIHR Oxford Biomedical Research Centre, Wellcome Centre for Human Genetics, University of Oxford, Oxford, OX3 7BN, UK, ${ }^{44}$ Division of Evolution and Genomic Sciences, Faculty of Biology, Medicine and Health, University of Manchester, Manchester, M13 9PL, UK, ${ }^{45}$ North East \& North Cumbria Genomic Medicine Centre, UK, ${ }^{46}$ Translational and Clinical Research Institute, Faculty of Medical Sciences, Newcastle University, Newcastle upon Tyne, NE1 3BZ, UK, ${ }^{47}$ National Institute for Health Research Newcastle Biomedical Research Centre, Newcastle upon Tyne, UK, ${ }^{48}$ Renal Services, The Newcastle Upon Tyne Hospitals National Health Service Trust, Newcastle upon Tyne, NE77DN, UK, ${ }^{49}$ NIHR BioResource, Cambridge University Hospitals, Cambridge Biomedical Campus, Cambridge, CB2 0QQ, UK, ${ }^{50}$ Cambridge Institute for Medical Research, University of Cambridge, Cambridge, CB2 OXY, UK, ${ }^{51}$ UK National External Quality Assessment Service for Molecular Genetics/Genomics Quality Assessment, Department of Laboratory Medicine, Royal Infirmary of Edinburgh, Edinburgh, UK, ${ }^{52} \mathrm{NHS}$ England and NHS Improvement, London, UK *contributed equally † joint last authors 
" correspondence to:

Arianna Tucci: William Harvey Research Institute, Queen Mary University of London, EC1M 6BQ, London, UK, a.tucci@qmul.ac.uk

Ryan J Taft: Illumina, Inc, 5200 Illumina Way San Diego, California, 92122, USA, rtaft@illumina.com

Michael A Eberle: Illumina, Inc, 5200 Illumina Way San Diego, California, 92122, USA, meberle@illumina.com 


\section{ABSTRACT}

Background: Repeat expansion (RE) disorders affect $\sim 1$ in 3000 individuals and are clinically heterogeneous diseases caused by expansions of short tandem DNA repeats. Genetic testing is often locus-specific, resulting in under diagnosis of atypical clinical presentations, especially in paediatric patients without a prior positive family history. Whole genome sequencing (WGS) is emerging as a first-line test for rare genetic disorders, but until recently REs were thought to be undetectable by this approach.

Methods: WGS pipelines for RE disorder detection were deployed by the 100,000 Genomes Project and Illumina Clinical Services Laboratory. Performance was retrospectively assessed across the 13 most common neurological RE loci using 793 samples with prior orthogonal testing (182 with expanded alleles and 611 with alleles within normal size) and prospectively interrogated in 13,331 patients with suspected genetic neurological disorders.

Findings: WGS RE detection showed minimum $97 \cdot 3 \%$ sensitivity and $99 \cdot 6 \%$ specificity across all 13 disease-associated loci. Applying the pipeline to patients from the 100,000 Genomes Project identified pathogenic repeat expansions which were confirmed in 69 patients, including seven paediatric patients with no reported family history of RE disorders, with a $0.09 \%$ false positive rate.

Interpretation: We show here for the first time that WGS enables the detection of causative repeat expansions with high sensitivity and specificity, and that it can be used to resolve 
previously undiagnosed neurological disorders. This includes children with no prior suspicion of a RE disorder. These findings are leading to diagnostic implementation of this analytical pipeline in the NHS Genomic Medicine Centres in England.

Funding: Medical Research Council, Department of Health and Social Care, National Health Service England, National Institute for Health Research, Illumina Inc

\section{INTRODUCTION}

Despite recent advances in our understanding of the genetic basis of rare neurological disorders, $\sim 70 \%$ of patients remain genetically undiagnosed. ${ }^{1}$ This is partly attributable to undertesting of genetic variants such as repeat expansions (RE), which are a leading cause of over 40 neurological disorders. ${ }^{2}$ RE disorders include the most common neurogenetic conditions, such as Huntington disease (HD), amyotrophic lateral sclerosis (ALS), frontotemporal dementia (FTD), and Fragile X syndrome, a common cause of intellectual disability. $^{2}$ RE disorders are clinically and genetically heterogeneous. The same repeat expansion can be associated with different phenotypes, within the same family. For example, C9orf72 is associated with both amyotrophic lateral sclerosis (ALS) and frontotemporal dementia (FTD). ${ }^{3}$ Furthermore, REs in different loci can present with overlapping phenotypic features, such as the spinocerebellar ataxia (SCA) genes, can present as an autosomal dominant cerebellar ataxia. ${ }^{4}$ 
RE disorders are associated with an increase in the number of repetitive short tandem DNA sequences, and the pathogenicity thresholds for each disorder are locus specific. These repeats exhibit molecular instability which can lead to changes in size across generations (generally increasing in length) and tissues. ${ }^{5}$ In these conditions, increases in the number of repeats often lead to earlier onset and more severe disease in successive generations within the same family. ${ }^{2}$ Paediatric onset of RE disorders can present as multi-system syndromes without specific phenotypic signatures, ${ }^{6}$ and are therefore more likely to be under-diagnosed and

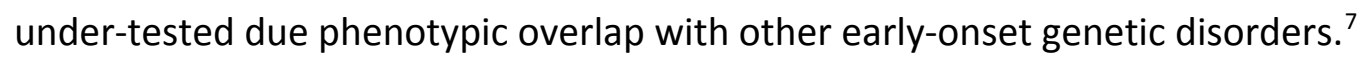

Laboratory assessment of REs includes targeted molecular assessment of individual loci, guided by the clinical diagnosis, using PCR-based or Southern blot ${ }^{8}$ assays which can be costly and time-consuming. Additionally, due to the the varied and overlapping phenotypic features of these disorders, most RE loci remain untested in an undiagnosed individual. ${ }^{9}$

Whole genome sequencing (WGS) is emerging as a first-line diagnostic tool in defined cases of rare disease ${ }^{10}$ but was previously thought to have limited capability to assess highly repetitive repeat expansion loci. ${ }^{11}$ Here, we report on the validation and deployment of a RE-aware WGS pipeline as part of the 100,000 Genomes Project (GE) and the Illumina Clinical Services Laboratory (ICSL), and its application to patients with undiagnosed neurological disorders (Figure 1). 


\section{METHODS}

\section{Whole genome sequencing}

DNA was prepared for sequencing using TruSeq DNA PCR-Free library preparation and 150 or

125 bp paired-end sequencing was performed on either HiSeq 2000 or HiSeq X platforms. Genomes were sequenced to an average minimum depth of 35X (31X - 37X) (Table S1).

\section{Repeat expansion performance datasets}

WGS RE performance was evaluated using data from two sources: 254 participants from the 100,000 Genomes Project at Genomics England (GE), and 150 individuals previously tested for expansions as part of clinical assessment from the NHS Genomic Laboratory based at Cambridge University Hospitals NHS Foundation Trust and used for External UK National Quality Assurance Schemes and sequenced in ICSL (Table S2, and Supplementary methods).

\section{PCR analysis}

RE were assessed by polymerase chain reaction (PCR) amplification and fragment analysis; Southern blotting was performed for large C9orf72 expansions. For additional details, including primer sequences see Supplementary methods. 


\section{Repeat expansion genotyping and visual inspection}

Short tandem repeat (STR) genotyping from whole genome sequencing was performed using the ExpansionHunter (EH) software package. ${ }^{12,13}$ In brief, EH assembles sequencing reads across a pre-defined set of STRs using both mapped and unmapped reads (with the repetitive sequence of interest) to estimate the size of both alleles from an individual (see Supplementary Methods). Recent guidelines from the Association for Medical Pathology and the College of American Pathologists recommend visual inspection of variant calls during routine sign out of NGS variants. ${ }^{14}$ However, short tandem repeat variants cannot be adequately visualised by common visualization tools such as IGV. ${ }^{15}$ To examine WGS data underlying each genotype call, we used a tool that creates a static visualization of the WGS reads containing the repeat identified by EH and used to support the repeat size estimate at each allele. This graph enables direct visualization of haplotypes and the corresponding read pileup of the EH genotypes (https://github.com/Illumina/GraphAlignmentViewer; Figure 2C and 2D). Visual inspection of the pileup graph was performed on all WGS-STR calls to (i) confirm the EH prediction for alleles entirely contained in each read (i.e. smaller than the sequencing read length); (ii) confirm the presence of a monoallelic or biallelic expansion; (iii) detect putative false positive calls; (iii) detect false negative alleles in biallelic repeat expansions, such as FXN (Supplementary methods, Figure S1). 


\section{0,000 Genomes Project patient inclusion criteria}

The 100,000 Genomes Project is a UK programme combining diagnostic discovery through research and clinical implementation to assess the value of WGS in individuals with unmet diagnostic needs in rare disease and cancer (Supplementary Methods). Following ethical approval (14/EE/1112) participants were enrolled in the 100,000 Genomes Project if they or their guardian had given research consent $(n=91,290)$. They were recruited by healthcare professionals and researchers as part of the Rare Disease cohort $(n=35,653)$ drawn from 13 Genomic Medicine Centres funded and established by NHS England in the National Health Service (NHS) in England. In this study participants with neurological phenotypes $(n=13,331)$ were assessed for RE expansions.

\section{RESULTS}

\section{Performance of the pipeline}

Thirteen pathogenic repeats, that represent a broad spectrum of the most common neurological repeat expansion disorders, were selected for performance assessment (Table S2). Specifically, eleven repeat expansion loci associated with ataxia and late-onset neurodegenerative disorders (all 'CAG' repeats: HTT, AR, ATN1, ATXN1, ATXN2, ATXN3, ATXN7, CACNA1A, and TBP plus C9orf72 and FXN), one locus associated with intellectual disability 
(FMR1) and one locus associated with myotonic dystrophy (DMPK). Each of these thirteen repeats had PCR validation data for at least one expanded allele (Table S2).

\section{Detection of expanded alleles}

In practice, repeat expansion detection requires accurate categorization of alleles into normal and expanded size ranges. To assess this, a combined set of 793 patient PCR tests, comprising 1,321 normal alleles (below premutation as detailed in Table S3) and 221 expanded alleles, covering all 13 disease loci, was established by GE and ICSL (Table S2). Comparing the EH output against this benchmark dataset showed a correct classification of 215 out of 221 expanded alleles and of 1,316 out of 1,321 normal alleles (Table S4, Table S5), showing a total sensitivity of $97 \cdot 3 \%$ (95\% Cl: $94 \cdot 2 \%-99 \%)$ and specificity of $99 \cdot 6 \%$ (95\% Cl:99·1\% - 99.9\%) (Table 1). All calls were visually inspected and re-classified as appropriate based on the quality of the reads supporting each call (Supplementary methods). Following the visual correction, sensitivity was $99 \cdot 1 \%(95 \% \mathrm{Cl}: 96 \cdot 7 \%-99 \cdot 9 \%)$ and specificity of $100 \%$ (95\% $\mathrm{Cl}: 99 \cdot 7 \%-100 \%)$

(Figure 2; Table 1). We note that visualization of the expanded calls was able to detect false positives and to re-classify all false negative alleles in $F X N$, where only one allele was classified as expanded in samples with biallelic expansions (see Supplementary methods, Figure S2, Figure S3).

As a further assessment of STR calling from WGS, repeat size estimates were compared with PCR-quantified lengths (Table S4). This dataset consisted of 418 PCR tests interrogating 805 alleles, $98 \%$ of which were normal and pre-mutation range (smaller than the WGS read-length 
(125bp or 150 bp) (see Supplementary methods for further details). 745 alleles sizes predicted by EH agreed with the PCR-assessed repeat lengths, yielding an overall concordance of $92.5 \%$. Locus variability was observed, with higher concordance for CACNA1A, ATXN2, and HTT and lower for TBP (Figure 2B, Table S6). These results are consistent with other studies showing a high concordance between WGS and PCR quantification of repeat lengths smaller than the sequencing read length. ${ }^{12,13,16}$

The benchmark dataset included large expansions in FMR1, DMPK, C9orf72, and FXN which can extend to up to $5 \mathrm{~kb}$ in size. EH was able to correctly identify expanded alleles at these loci (Table S5), although EH size estimates trended lower as repeat size increased within the pathogenic range (Figure 2, Table S7), and this affected the ability to distinguish between large and small expansions in DMPK or between full-expansions and premutations in FMR1 (Table S7).

\section{Detection of pathogenic repeat expansions in undiagnosed individuals}

To incorporate WGS-based repeat expansion detection within the clinical diagnostic setting, we applied our EH-enabled pipeline to WGS 13,331 individuals with a suspected genetic neurological disorder recruited to the 100,000 Genomes Project dataset. These individuals were drawn from four cohorts: (A) patients with a neurodegenerative disorder, including early onset dementia (C9orf72), amyotrophic lateral sclerosis (C9orf72, and AR), hereditary ataxia (ATN1, 
ATXN1, ATXN2, ATXN3, ATXN7, CACNA1A, FXN, and TBP), hereditary spastic paraplegia (FXN), Charcot-Marie-Tooth $(A R)$ andand early onset or complex parkinsonism (ATXN2, ATXN3) due to their overlapping presentations ( $n=3,626$; Table 2); (B) paediatric patients with intellectual disability (ID) and seizures, dystonia, ataxia, spastic paraplegia, optic neuropathy, retinopathy, white matter abnormalities, muscular, or hypotonia $(n=2,576$; Table 2 and Supplementary Methods) which were assessed for 'CAG' expansions in HTT, ATN1, ATXN2, ATXN3, CACNA1A, and $A T X N 7$, as these REs have been reported to cause rare paediatric diseases. ${ }^{17,18}$; (C) paediatric and adult patients presenting with intellectual disability, a neuromuscular phenotype or a combination of the two ( $n=7,592$; Table 2$)$ assessed for DMPK expansions; and (D) paediatric patients presenting with intellectual disability alone analysed for FMR1 expansions $(n=6,731 ;$ Table 2).

Individuals who had previously tested negative after usual care testing in the NHS and participants with suspected monogenic disease and no prior molecular testing were eligible. Despite usual care NHS genomic testing being negative, we detected and visually confirmed repeat expansions in 96 individuals (Table S8). Of these, 82 cases were available for orthogonal testing, and 69 full expansions (Table S9). At the time of writing, diagnostic reports have been issued for 60 patients. Clinical details of the 69 individuals with full expansions are provided in Table 3 and Table S10. Of the six EH calls that were not orthogonally confirmed, two were normal alleles in ATXN1 and ATXN2, and four were FMR1 intermediate range calls $(\mathrm{n}=4)$ (Figure S5). These results demonstrate that the RE aware WGS pipeline was successfully deployed at scale with a $0.09 \%$ false positive rate (13 false positive tests out of 13,331 individuals tested). 
In cohort A, expansions were observed in individuals presenting with a wide variety of overlapping phenotypes (Table 3), including an ATXN2 RE in a individual with Levodopa-responsive early-onset Parkinson's disease and a history of progressive cerebellar ataxia, an $A R$ expansion in individuals clinically diagnosed with Charcot-Marie-Tooth disease including one with demyelinating neuropathy i.e. CMT1. Further, a wide range of prior clinical diagnoses were observed in individuals with pathogenic repeat expansions. For example, in seven individuals with amyotrophic lateral sclerosis or motor neuron disease, expansions were identified in $A R(\mathrm{n}=4)$ and C9orf72 $(\mathrm{n}=3)$. In participants recruited under hereditary ataxia we identified expansions in loci that had not been assessed within the NHS at the time of recruitment, including ATN1, ATXN2, ATXN3, ATXN7, CACNA1A, FXN, TBP (Table 3). We also detected RES in individuals with a phenotype that was consistent with a different repeat expansion disorder, e.g. a C9orf72 expansion in early onset and familial Parkinson's Disease (case 27 , Table 3 ), and repeat expansions in the reduced penetrance range (38 repeats in HTT in two sisters with movement disorder, dementia, depression and speech difficulties, cases 40 and 41 Table S10) underscoring the diagnostic challenge presented by these disorders. Taken together, these data demonstrate that the diagnosis challenges due the complexity of overlapping and pleiotropic presentation of repeat expansions disorders in adults can be reduced with a whole genome testing approach.

Strikingly, seven children in cohort B were identified with large 'CAG' expansions (Figure 3). Six lacked any informative family history and had not been offered RE testing as part of their clinical genomic testing at the time of recruitment (Table 3). Two children under the age of 10 
carried large HTT expansions (90-100 'CAG' repeats). Remarkably, one child had inherited the repeat from an unaffected parent with no family history of Huntington disease. Family testing is ongoing, but a reduced penetrance allele has been identified in the wider family, indicating that the repeat had expanded by over 60 repeat units in a single generation (case 52, Table 3). Two children under the age of five carried large ATXN7 expansions and presented with complex multi-system phenotypes. This included a girl (case 46, Table 3), whose parent began to show gait problems two years after enrolment in the 100,000 Genomes Project. Similarly, a ten year old girl with an indication for testing of intellectual disability was found to have a ATXN2 expansion of 99 repeats, despite both parents recruited to the project being designated as 'unaffected', and a 18 year old girl with dementia was found to carry an 69 repeat expansion in ATN1 (Table 3). These data suggest that genome-wide testing of repeat loci can resolve cryptic pediatric genetic disease cases.

In cohort $\mathrm{C}$, seven expansions in DMPK were confirmed in five families, including a child and a mother with a clinical diagnosis of muscular dystrophy, two siblings with a suspected 'distal myopathy' disease (cases 53 and 54 Table 3), and one case with a suspected ataxia that also presented with muscular weakness (case 58). Lastly, in cohort D, FMR1 expansions were detected in seven males, where a diagnosis of Fragile $\mathrm{X}$ syndrome fully or partially explained the presenting phenotype (cases 60-66, Table 3). 


\section{DISCUSSION}

The diagnosis of RE disorders is challenging in healthcare due to heterogeneous clinical presentations, overlapping phenotypes and non-specific clinical findings, which may increase in severity with age, and in each subsequent generation. Repeat expansion disorders are amongst the most common causes of inherited neurological diseases. ${ }^{2}$ Nonetheless, patients may be underdiagnosed because of the fragmented testing approaches currently employed - they may have the incorrect repeat expansion locus tested ${ }^{19}$ or receive a molecular test for a different class of variant due to the phenotypic overlap with other neurological genetic disorders. ${ }^{20}$

WGS has been deployed in multiple settings as a first line diagnostic test for rare neurological disorders, but has previously been thought to have limited ability to detect repeat expansions. ${ }^{11}$ Recently, several tools have been developed to call repeats from WGS in the research setting. ${ }^{21}$ However, none has been implemented in a clinical setting. In this study, we present evidence that a WGS bioinformatic pipeline incorporating an accurate expansion-aware algorithm can reliably assess the most common disease-causing repeat expansions and resolve previously intractable cases in a large cohort of patients with genetically undiagnosed neurological disorders.

When WGS RE detection was assessed against positive and negative controls previously characterized in clinical diagnostic genomic laboratories using gold standard methods, we found an overall minimum $97.3 \cdot 6 \%$ sensitivity and $99 \cdot 6 \%$ specificity. This reflects the ability of 
the pipeline to accurately discriminate between normal and disease-causing alleles across $13 \mathrm{RE}$ disorder loci. Furthermore, these data show that repeat sizing is accurate for repeats smaller than the sequencing read lengths, and therefore most normal and premutation alleles for the 'CAG' repeat expansion disorders can be sized accurately. The WGS expansion detection pipeline is limited in its sizing of alleles significantly larger than the read-length, such as Fragile X. For example, we note that all FMR1 repeats previously classified by PCR as 'expanded' were classified by WGS as premutation in this study.

Our findings enable the establishment of a clinical diagnostic workflow for WGS (Figure S6) in which repeat expansions are classified as either 'normal' or 'expanded' (i.e. larger than the premutation cut-off) without adherence to the repeat size estimation, particularly for large repeats. We propose that all WGS-calls classified as 'expanded' are visually inspected to detect false positive calls (Figure S2) and detect the presence of biallelic expansions where only one expanded allele has been detected (e.g. FXN) (cases A-C, Figure S3). Additionally, we recommend that after visual confirmation the presence of the expansion is validated by orthogonal testing.

The application of the WGS-pipeline to undiagnosed patients tested in the ICSL laboratory has led to five RE diagnoses (in $A T X N 2, F X N \& D M P K$ ), including the detection of pathogenic mosaic maternal expansions. In participants recruited to the 100,000 Genomes Project, pathogenic REs consistent with the patient's phenotypes have been diagnostically confirmed in 60 cases. Remarkably, some of the expansions were not suspected based on the patient phenotype, including six paediatric subjects without any family history of a RE disorder. The average repeat 
expansion sizes detected across the paediatric cases described here are substantially larger than the average in adults, strongly suggesting that using age-specific repeat-size thresholds may eliminate any potential hazard of identifying adult-onset risk alleles in children (Figure 3).

Rare inherited diseases may present with a wide phenotypic spectrum that often overlaps multiple different syndromes making locus specific genomic testing inefficient, arduous, and expensive. We present evidence here that a clinical grade WGS bioinformatic pipeline, with potential to diagnose a range of rare neurologic diseases, may now be extended to identify REs. Since WGS provides a single test that can identify the most common REs, it offers the opportunity to identify the majority of patients with these heterogeneous disabling disorders where the diagnosis may be missed by locus-specific testing. In the era of emerging therapies for these disorders early detection may become crucial. ${ }^{22}$ As a result this is now being considered for adoption in the NHS England National Genomic Test Directory for application to undiagnosed rare neurologic disease in direct healthcare.

\section{REFERENCES}

1. Ngo KJ, Rexach JE, Lee H, Petty LE, Perlman S, Valera JM, et al. A diagnostic ceiling for exome sequencing in cerebellar ataxia and related neurological disorders. Hum Mutat [Internet]. 2020 [cited 2020 Oct 14];41(2):487-501. Available from: https://onlinelibrary.wiley.com/doi/abs/10.1002/humu.23946

2. Paulson H. Chapter 9 - Repeat expansion diseases. In: Geschwind DH, Paulson HL, Klein C, editors. Handbook of Clinical Neurology [Internet]. Elsevier; 2018 [cited 2020 Oct 14]. p. 105-23. (Neurogenetics, Part I; vol. 147). Available from: 
http://www.sciencedirect.com/science/article/pii/B9780444632333000099

3. Cruts M, Engelborghs S, Zee J van der, Broeckhoven CV. C9orf72-Related Amyotrophic Lateral Sclerosis and Frontotemporal Dementia [Internet]. GeneReviews ${ }^{\circledR}$ [Internet]. University of Washington, Seattle; 2015 [cited 2020 Oct 14]. Available from: https://www.ncbi.nlm.nih.gov/books/NBK268647/

4. Shakkottai VG, Fogel BL. Clinical Neurogenetics: Autosomal Dominant Spinocerebellar Ataxia. Neurol Clin [Internet]. 2013 Nov 1 [cited 2020 Oct 14];31(4):987-1007. Available from: http://www.sciencedirect.com/science/article/pii/S0733861913000455

5. Martino D, Stamelou M, Bhatia KP. Review: The differential diagnosis of Huntington's disease-like syndromes: 'red flags' for the clinician. J Neurol Neurosurg Psychiatry [Internet]. 2013 Jun [cited 2020 Oct 14];84(6):650. Available from: https://www.ncbi.nlm.nih.gov/pmc/articles/PMC3646286/

6. Gousse G, Patural H, Touraine R, Chabrier S, Rolland E, Antoine J-C, et al. Lethal form of spinocerebellar ataxia type 7 with early onset in childhood. Arch Pédiatrie [Internet]. 2018 Jan 1 [cited 2020 Nov 2];25(1):42-4. Available from: http://www.sciencedirect.com/science/article/pii/S0929693X17304669

7. Ansorge $O$, Giunti P, Michalik A, Van Broeckhoven C, Harding B, Wood N, et al. Ataxin-7 aggregation and ubiquitination in infantile SCA7 with 180 CAG repeats. Ann Neurol. 2004 Sep;56(3):448-52.

8. Bird TD. Myotonic Dystrophy Type 1. In: Adam MP, Ardinger HH, Pagon RA, Wallace SE, Bean LJ, Stephens K, et al., editors. GeneReviews ${ }^{\circledR}$ [Internet]. Seattle (WA): University of Washington, Seattle; 1993 [cited 2020 Oct 14]. Available from: http://www.ncbi.nlm.nih.gov/books/NBK1165/

9. Aydin G, Dekomien G, Hoffjan S, Gerding WM, Epplen JT, Arning L. Frequency of SCA8, SCA10, SCA12, SCA36, FXTAS and C9orf72 repeat expansions in SCA patients negative for the most common SCA subtypes. BMC Neurol. 2018 Jan 9;18(1):3.

10. Turro E, Astle WJ, Megy K, Gräf S, Greene D, Shamardina O, et al. Whole-genome sequencing of patients with rare diseases in a national health system. Nature [Internet]. $2020 \mathrm{Jul}$ [cited 2020 Oct 14];583(7814):96-102. Available from: https://www.nature.com/articles/s41586-020-2434-2

11. Ashley EA. Towards precision medicine. Nat Rev Genet [Internet]. 2016 Sep [cited 2020 Oct 14];17(9):507-22. Available from: https://www.nature.com/articles/nrg.2016.86

12. Dolzhenko E, Vugt JJFA van, Shaw RJ, Bekritsky MA, Blitterswijk M van, Narzisi G, et al. Detection of long repeat expansions from PCR-free whole-genome sequence data. Genome Res [Internet]. 2017 Nov [cited 2020 Oct 14];27(11):1895. Available from: https://www.ncbi.nlm.nih.gov/pmc/articles/PMC5668946/

13. Dolzhenko E, Deshpande V, Schlesinger F, Krusche P, Petrovski R, Chen S, et al. ExpansionHunter: a sequence-graph-based tool to analyze variation in short tandem repeat regions. Bioinformatics [Internet]. 2019 Nov 1 [cited 2020 Oct 14];35(22):4754-6. Available from: https://doi.org/10.1093/bioinformatics/btz431

14. Roy S, Coldren C, Karunamurthy A, Kip NS, Klee EW, Lincoln SE, et al. Standards and Guidelines for Validating Next-Generation Sequencing Bioinformatics Pipelines: A Joint Recommendation of the Association for Molecular Pathology and the College of American 
Pathologists. J Mol Diagn JMD. 2018 Jan;20(1):4-27.

15. Robinson JT, Thorvaldsdóttir H, Winckler W, Guttman M, Lander ES, Getz G, et al. Integrative genomics viewer. Nat Biotechnol [Internet]. 2011 Jan [cited 2020 Nov 2];29(1):24-6. Available from: https://www.nature.com/articles/nbt.1754

16. Tazelaar GHP, Boeynaems S, De Decker M, van Vugt JJFA, Kool L, Goedee HS, et al. ATXN1 repeat expansions confer risk for amyotrophic lateral sclerosis and contribute to TDP-43 mislocalization. Brain Commun [Internet]. 2020 May 19 [cited 2020 Oct 23];2(2). Available from: https://www.ncbi.nlm.nih.gov/pmc/articles/PMC7425293/

17. Veneziano L, Frontali M. DRPLA. In: Adam MP, Ardinger HH, Pagon RA, Wallace SE, Bean LJ, Stephens K, et al., editors. GeneReviews ${ }^{\circledR}$ [Internet]. Seattle (WA): University of Washington, Seattle; 1993 [cited 2020 Oct 16]. Available from: http://www.ncbi.nlm.nih.gov/books/NBK1491/

18. Fusilli C, Migliore S, Mazza T, Consoli F, De Luca A, Barbagallo G, et al. Biological and clinical manifestations of juvenile Huntington's disease: a retrospective analysis. Lancet Neurol. 2018;17(11):986-93.

19. Schneider SA, van de Warrenburg BPC, Hughes TD, Davis M, Sweeney M, Wood N, et al. Phenotypic homogeneity of the Huntington disease-like presentation in a SCA17 family. Neurology. 2006 Nov 14;67(9):1701-3.

20. Schneider SA, Bird T. Huntington's Disease, Huntington's Disease Look-Alikes, and Benign Hereditary Chorea: What's New? Mov Disord Clin Pract [Internet]. 2016 [cited 2020 Oct 14];3(4):342-54. Available from: https://onlinelibrary.wiley.com/doi/abs/10.1002/mdc3.12312

21. Rafehi H, Szmulewicz DJ, Bennett MF, Sobreira NLM, Pope K, Smith KR, et al. Bioinformatics-Based Identification of Expanded Repeats: A Non-reference Intronic Pentamer Expansion in RFC1 Causes CANVAS. Am J Hum Genet. 2019 Jul 3;105(1):151-65.

22. Ellerby LM. Repeat Expansion Disorders: Mechanisms and Therapeutics. Neurotherapeutics [Internet]. 2019 Oct 1 [cited 2020 Oct 29];16(4):924-7. Available from: https://doi.org/10.1007/s13311-019-00823-3 


\section{Conflicts of Interest}

Genomics England Ltd is a wholly owned Department of Health and Social Care company created in 2013 to introduce WGS into healthcare in conjunction with NHS England. All Genomics England affiliated authors are, or were, salaried by or seconded to Genomics England. RJT, ME, ED, RTH are employees and shareholders of Illumina Inc.

\section{Acknowledgements}

Genomics England and the 100,000 Genomes Project was funded by the National Institute for Health Research, the Wellcome Trust, the Medical Research Council, Cancer Research UK, the Department of Health and Social Care and NHS England. We thank all the participants and healthcare teams at the 13 NHS Genomic Medicine Centres where 5000 multidisciplinary staff enrolled patients to the 100,000 Genomes Project in the East of England, Greater Manchester, North East and North Cumbria, North Thames, North West Coast, Oxford, South London, West London, West Midlands, South West, Wessex, West of England and Yorkshire and Humber. Participants were also enrolled from Scotland by the Scottish Genomes Project, across Wales and Northern Ireland.

This work forms part of the portfolio of translational research at the NIHR Biomedical Research Centres at Barts, Birmingham, Bristol, Cambridge, Great Ormond Street Foundation, Guy's and St Thomas's, Imperial, Leeds, Leicester, Manchester, Maudsley, Moorfields, Newcastle, Nottingham, Oxford, Royal Marsden, Sheffield, Southampton and University College London.

This work was made possible through the generosity of NHS patients and their families and 
uses clinical data from the NHS and NHS Digital. The views expressed are those of the author(s) and not necessarily those of the NHS, the NIHR or the Department of Health and Social Care.

Mark Caulfield is an NIHR Senior Investigator. Patrick Chinnery is a Wellcome Trust Principal Research Fellow (212219/Z/18/Z), and an NIHR Senior Investigator, who receives support from the Medical Research Council Mitochondrial Biology Unit (MC_UU_00015/9), the Medical Research Council (MRC) International Centre for Genomic Medicine in Neuromuscular Disease (MR/S005021/1), the Leverhulme Trust (RPG-2018-408), an MRC research grant (MR/S035699/1), an Alzheimer's Society Project Grant (AS-PG-18b-022). John Sayer is supported by Kidney Research UK (RP_006_20180227). Richard Festenstein receives support from Imperial NIHR BRC. Jonathan M Schott receives support from National Institute for Health Research University College London Hospitals Biomedical Research Centre, Brain Research UK (UCC14191) and Medical Research Council. Lyn S Chitty is an NIHR Senior Investigator and is partly funded by GOSH NIHR Biomedical Research Centre, which has provided infrastructure support for the North Thames GMC. Arianna Tucci is an MRC Clinician Scientist (MR/S006753/1).

We thank Illumina Clinical Laboratory Sciences, San Diego and Illumina, San Diego and Granta Park Cambridge for undertaking whole genome sequencing and validation of true positives and negatives. We are grateful for the support of Dom McMullan, Helen Firth, Steve Abbs, Sian Ellard for their role in supporting the development of the bioinformatics pipeline and reporting process. We are grateful for the input and support from Professor Dame Sue Hill and the team in NHS England and for the work to fund and establish the 13 Genomic Medicine Centres. This 
enabled the NHS contribution to the 100,000 Genomes Project by enrolment of patients, receipt of the results and in some cases orthogonal validation using standardised approaches including return of findings for direct patient benefit.

\section{FIGURE LEGENDS}

Figure 1. Evaluation of WGS repeat expansion detection performance and its application to patients with genetically undiagnosed disorders. In this study, thirteen well-established repeat expansion disorders were selected for interrogation by whole genome sequencing. Performance was assessed against 221 expanded and 1321 normal alleles drawn from samples tested at Neurogenetics Laboratory at the National Hospital for Neurology and Neurosurgery and Genetics Laboratory, Cambridge University Hospitals NHS Foundation Trust (see Methods and Supplemental Methods). WGS was performed at a minimum of 35x depth and each disease locus was interrogated using the Expansion Hunter software package (see Methods and Supplemental Methods). Expansion detection performance for each locus was assessed against the pre-mutation cutoff (Table S3). Within this dataset we observed an overall sensitivity of $98.2 \%$ and specificity of $99.9 \%$, which when applied to individuals with a genetically undiagnosed disorder from the 100,000 Genomes Project (Genomics England, GE), or tested by the Illumina Clinical Services Laboratory (ICSL) revealed previously undetected expansions in AR, ATN1, ATXN1, ATXN2, ATXN3, ATXN7, CACNA1A, C9orf72, HTT, TBP, DMPK, and FXN. 
Figure 2. Repeat expansion detection performance using whole genome sequencing. A) Swim lane plot. Sizes of repeat-unit expansions predicted by ExpansionHunter across 793 expansion calls. Each genome assessed is represented by two points corresponding to each allele for each locus, with the exception of those on chromosome $\mathrm{X}$ (i.e. FMR1, AR) in males. Points indicate the sequencing based repeat length and the colors indicate the repeat size as assessed by PCR (blue = PCR-normal; red $=$ PCR-expanded). The regions are shaded to indicate normal (blue), premutation (yellow), and expansion (light red) ranges for each gene as indicated in Table S3. Blue points in yellow or red shaded regions indicate false positives and the red points in blue shaded regions indicate false negatives. There are five genomes with $\sim 500$ repeats in C9orf72 that are shown here as 200 to facilitate reasonable $X$ axis scaling. The individual calls are provided in Table S4. B) Repeat-size accuracy split by locus. Bubble-plot representing PCR and EH repeat-sizes in $X$ and $Y$ axis respectively, and the size of each dot showing the number of cases with the same repeat-size. There are two layers, one in grey, and the other colored. The difference between them is the values of the $\mathrm{Y}$ axis, being the $\mathrm{EH}$ estimations before visual inspection for the grey scenario, and the corrected EH sizes after visual inspection for the coloured layer. Vertical and horizontal red dot dashed lines represent the premutation cut-off (Table S3) for each locus. C) Characteristic pileup graph. A characteristic pileup graph illustrating a call in ATXN2 where the estimated genotype for 'GCT' repeat unit is 22/40. Reads supporting each genotype are grouped based on the predicted genotype, in this example in three groups: i) two reads supporting 40 repeat units, in the pathogenic range, on the top of the graph; ii) reads flanking the repeat, supporting > 39 repeat units, in the middle; iii) nine reads supporting 22 repeat units, bottom of the graph. D) Schematic representation of the 
pileup graph. Each read has been coloured according to its sequence content, with blue representing the sequence flanking the repeat, and brown the repeated sequence.

Figure 3. Adult and paediatric cases showing pathogenic expanded repeats. Repeat size frequency distribution of $\operatorname{ATN1}(\mathrm{A}), \operatorname{ATXN2}(\mathrm{B}), \operatorname{ATXN7}(\mathrm{C})$, and $H T T$ (D) in 13,331 individuals; 'CAG' repeat count in $\mathrm{X}$ axis; allele count in $\mathrm{Y}$ axis. The dotted red line represents the full mutation threshold for each locus (Table S3). White and red arrowheads indicate adult and paediatric pathogenic expansions respectively.

\section{TABLES}

Table 1. WGS repeat expansion detection performance Performance based on total number of normal and expanded alleles across all loci tested after visual inspection. TN = True Negative; FP = False Positive; TP = True Positive; FN = False negative

\begin{tabular}{|c|c|c|c|c|c|c|c|c|}
\hline & \multicolumn{4}{|c|}{ EHv3.1.2 } & \multicolumn{4}{|c|}{ EHv312 after visual QC } \\
\hline & $\mathrm{TN}$ & FP & $\mathrm{TP}$ & $\mathrm{FN}$ & TN & FP & TP & FN \\
\hline Total alleles & 1316 & 5 & 215 & 6 & 1321 & 0 & 219 & 2 \\
\hline Specificity & & \multicolumn{2}{|c|}{$99 \cdot 6 \%$} & & & $100 \%$ & o 1009 & \\
\hline
\end{tabular}




\begin{tabular}{|l|c|c|}
\hline Sensitivity & $97 \cdot 3 \%$ & $99 \cdot 1 \%$ \\
\hline Positive Predictive & $(95 \% \mathrm{Cl}: 94 \cdot 2 \%$ to $99 \%)$ & (95\% Cl: $96 \cdot 8 \%$ to $99 \cdot 9 \%)$ \\
Value & $97 \cdot 7 \%$ & $100 \%$ \\
\hline Negative Predictive & $(95 \% \mathrm{Cl}: 94 \cdot 7 \%$ to $99 \%)$ & $99 \cdot 9 \%$ \\
\hline Value & $99 \cdot 6 \%$ & $(95 \% \mathrm{Cl}: 99 \cdot 4 \%$ to $100 \%)$ \\
\hline Accuracy & $(95 \% \mathrm{Cl}: 99 \%$ to $99 \cdot 8 \%)$ & $100 \%$ \\
& $(95 \% \mathrm{Cl}: 98 \cdot 7 \%$ to $99 \cdot 6 \%)$ & $(95 \% \mathrm{Cl}: 99 \cdot 5 \%$ to $100 \%)$ \\
\hline
\end{tabular}


Table 2. 100,000 Genomes Project cohort analysed to identify pathogenic RE

Total number of patients, median age, and percentage of biological sex for each subsection. See

Table S14 for ancestry information.

\begin{tabular}{|c|c|c|c|}
\hline & $\begin{array}{c}\text { Total number of } \\
\text { patients }\end{array}$ & $\begin{array}{c}\text { Age: } \\
\text { Median (range) }\end{array}$ & $\begin{array}{c}\text { Biological sex (\%) } \\
\text { males:females }\end{array}$ \\
\hline Overall & 13331 & $\begin{array}{c}17 \\
(9-45)\end{array}$ & $56 \%-44 \%$ \\
\hline Hereditary ataxia & 1182 & $\begin{array}{c}57 \\
(41-70)\end{array}$ & $50 \%-50 \%$ \\
\hline Hereditary spastic paraplegia & 526 & $\begin{array}{c}48 \\
(35-62)\end{array}$ & $52 \cdot 5 \%-47 \cdot 5 \%$ \\
\hline Early onset and familial & 520 & $\begin{array}{c}56 \\
(50-66)\end{array}$ & $58 \%-42 \%$ \\
\hline
\end{tabular}




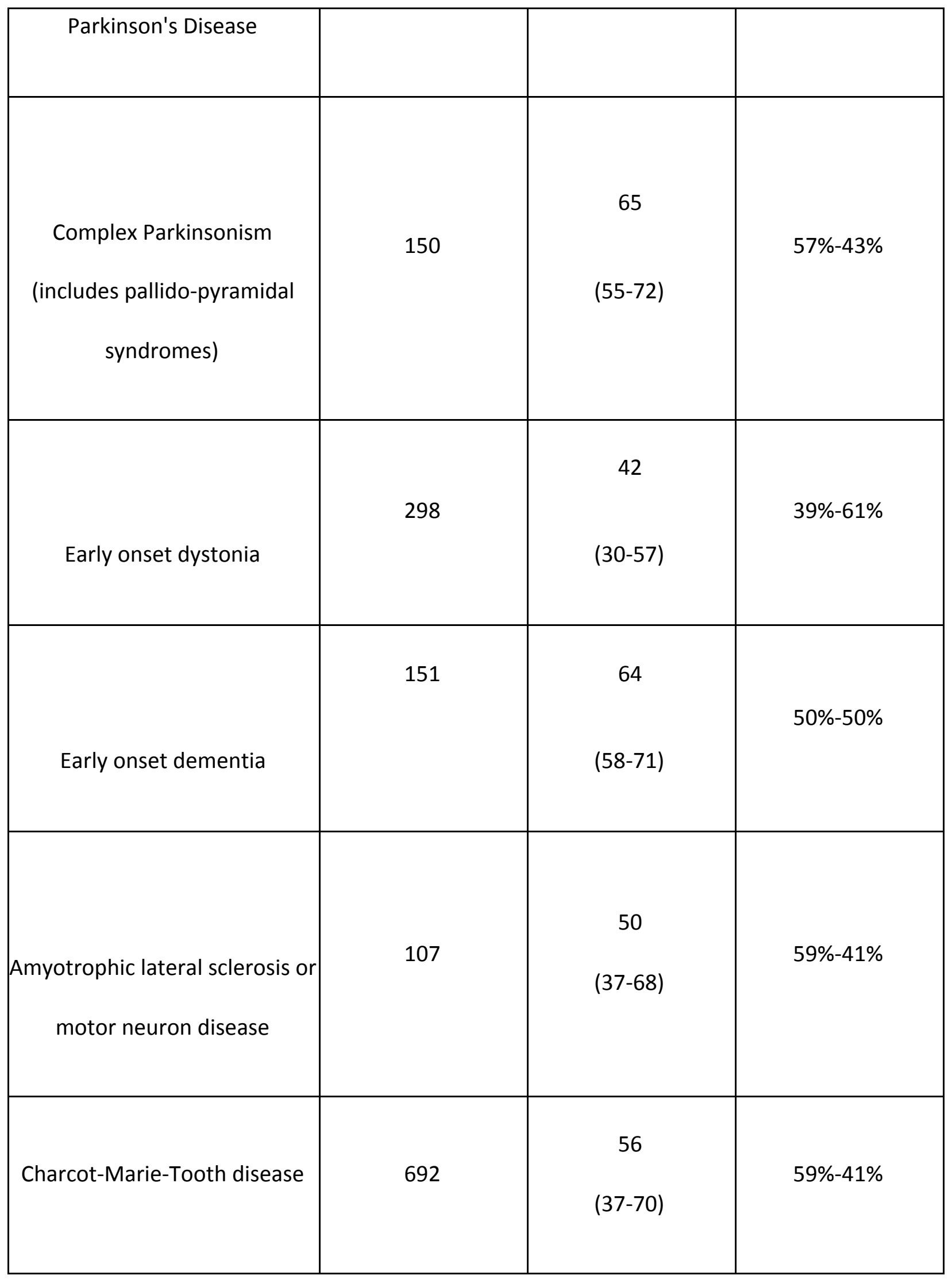




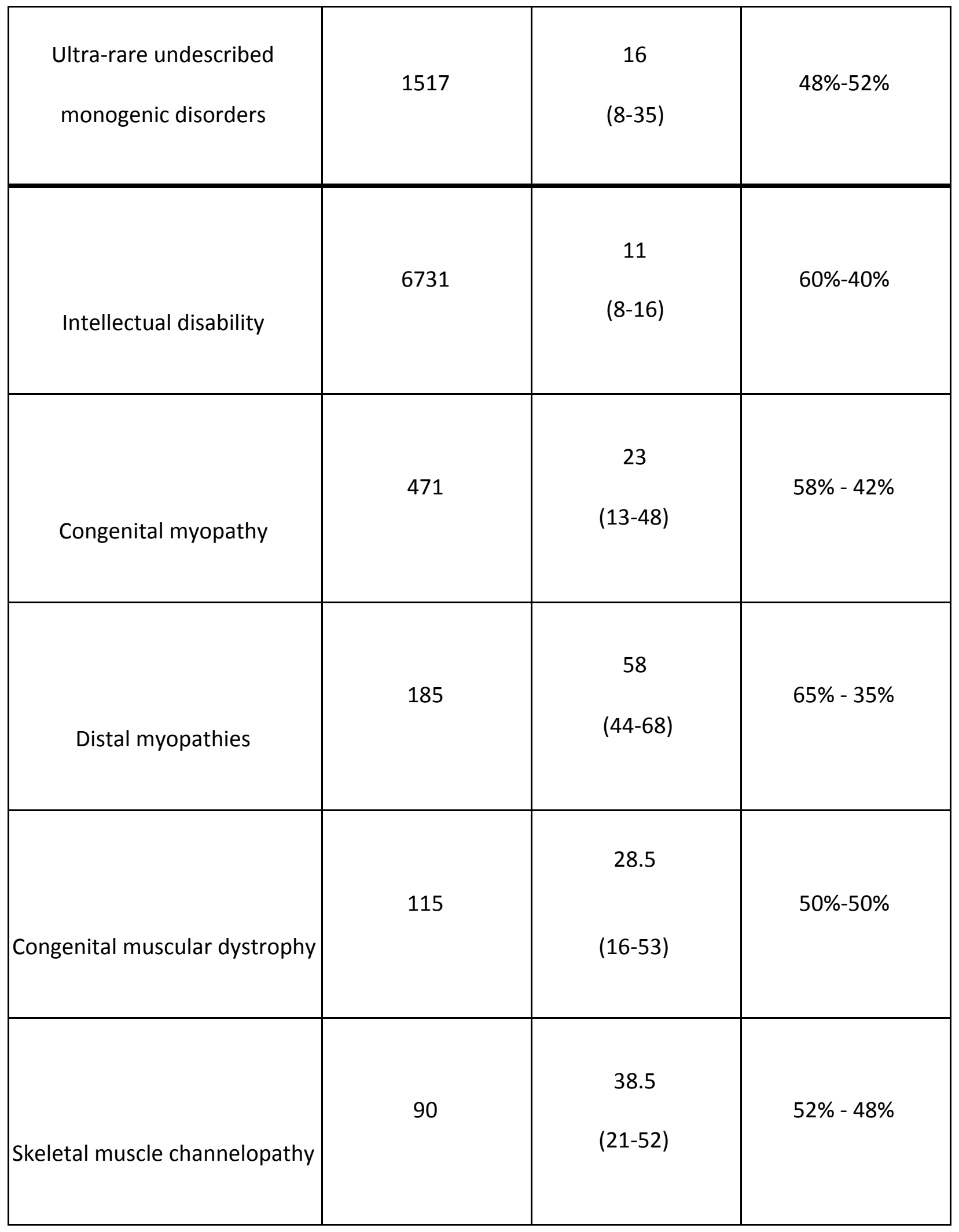


bioRxiv preprint doi: https://doi.org/10.1101/2020.11.06.371716; this version posted November 6, 2020. The copyright holder for this preprint (which was not certified by peer review) is the author/funder. All rights reserved. No reuse allowed without permission. 
Table 3. 100,000 Genomes Project patients with pathogenic expansions.

Patients with pathogenic expansions in the 100,000 Genomes Project. For each disease and gene ('Gene' and 'Phenotype, 'MIM number' fields), information regarding the disease name under which a participant has been recruited together with biological sex, age range, and the genotypes are shown. The genotypes correspond to EHv2.5.5 sizes. The table is split into different disease groups ('Cohort'). See Table S10 for additional details including list of HPO terms for each individual.

\begin{tabular}{|c|c|c|c|c|c|c|c|c|}
\hline Cohort & Gene & $\begin{array}{c}\text { Phenotype, MIM } \\
\text { number }\end{array}$ & $\begin{array}{l}\text { Case } \\
\text { ID }\end{array}$ & $\begin{array}{l}\text { Recruited } \\
\text { disease }\end{array}$ & $\begin{array}{l}\text { Biolog } \\
\text { ical } \\
\text { sex }\end{array}$ & $\begin{array}{l}\text { Age } \\
\text { group }\end{array}$ & GT1 & GT2 \\
\hline $\begin{array}{c}\text { Ataxia and } \\
\text { adult } \\
\text { neurodegenera } \\
\text { tive }\end{array}$ & $\begin{array}{l}\text { Androgen } \\
\text { Receptor;AR }\end{array}$ & $\begin{array}{l}\text { Spinal and bulbar } \\
\text { muscular atrophy } \\
\text { of Kennedy, } 313200\end{array}$ & 1 & $\begin{array}{l}\text { Charcot-Mari } \\
\text { e-Tooth } \\
\text { disease }\end{array}$ & $M$ & $61-70$ & 57 & NA \\
\hline
\end{tabular}




\begin{tabular}{|c|c|c|c|c|c|c|c|c|}
\hline $\begin{array}{c}\text { Ataxia and } \\
\text { adult } \\
\text { neurodegenera } \\
\text { tive }\end{array}$ & $\begin{array}{l}\text { Androgen } \\
\text { Receptor;AR }\end{array}$ & $\begin{array}{l}\text { Spinal and bulbar } \\
\text { muscular atrophy } \\
\text { of Kennedy, } 313200\end{array}$ & 2 & $\begin{array}{l}\text { Amyotrophic } \\
\text { lateral } \\
\text { sclerosis or } \\
\text { motor neuron } \\
\text { disease }\end{array}$ & $M$ & $51-60$ & 55 & NA \\
\hline $\begin{array}{l}\text { Ataxia and } \\
\text { adult } \\
\text { neurodegenera } \\
\text { tive }\end{array}$ & $\begin{array}{l}\text { Androgen } \\
\text { Receptor;AR }\end{array}$ & $\begin{array}{l}\text { Spinal and bulbar } \\
\text { muscular atrophy } \\
\text { of Kennedy, } 313200\end{array}$ & 3 & $\begin{array}{l}\text { Amyotrophic } \\
\text { lateral } \\
\text { sclerosis or } \\
\text { motor neuron } \\
\text { disease }\end{array}$ & $\mathrm{F}$ & $71-80$ & 54 & 22 \\
\hline $\begin{array}{l}\text { Ataxia and } \\
\text { adult } \\
\text { neurodegenera } \\
\text { tive }\end{array}$ & $\begin{array}{l}\text { Androgen } \\
\text { Receptor;AR }\end{array}$ & $\begin{array}{l}\text { Spinal and bulbar } \\
\text { muscular atrophy } \\
\text { of Kennedy, } 313200\end{array}$ & 4 & $\begin{array}{l}\text { Amyotrophic } \\
\text { lateral } \\
\text { sclerosis or } \\
\text { motor neuron } \\
\text { disease }\end{array}$ & $\mathrm{M}$ & $41-50$ & 52 & NA \\
\hline $\begin{array}{c}\text { Ataxia and } \\
\text { adult } \\
\text { neurodegenera } \\
\text { tive }\end{array}$ & $\begin{array}{l}\text { Androgen } \\
\text { Receptor;AR }\end{array}$ & $\begin{array}{l}\text { Spinal and bulbar } \\
\text { muscular atrophy } \\
\text { of Kennedy, } 313200\end{array}$ & 5 & $\begin{array}{l}\text { Charcot-Mari } \\
\text { e-Tooth } \\
\text { disease }\end{array}$ & $\mathrm{M}$ & $41-50$ & 43 & NA \\
\hline
\end{tabular}




\begin{tabular}{|c|c|c|c|c|c|c|c|c|}
\hline $\begin{array}{c}\text { Ataxia and } \\
\text { adult } \\
\text { neurodegenera } \\
\text { tive }\end{array}$ & $\begin{array}{l}\text { Androgen } \\
\text { Receptor;AR }\end{array}$ & $\begin{array}{l}\text { Spinal and bulbar } \\
\text { muscular atrophy } \\
\text { of Kennedy, } 313200\end{array}$ & 6 & $\begin{array}{l}\text { Charcot-Mari } \\
\text { e-Tooth } \\
\text { disease }\end{array}$ & $\mathrm{M}$ & $21-30$ & 41 & NA \\
\hline $\begin{array}{c}\text { Ataxia and } \\
\text { adult } \\
\text { neurodegenera } \\
\text { tive }\end{array}$ & $\begin{array}{l}\text { Androgen } \\
\text { Receptor;AR }\end{array}$ & $\begin{array}{l}\text { Spinal and bulbar } \\
\text { muscular atrophy } \\
\text { of Kennedy, } 313200\end{array}$ & 7 & $\begin{array}{l}\text { Charcot-Mari } \\
\text { e-Tooth } \\
\text { disease }\end{array}$ & $\mathrm{M}$ & $21-30$ & 40 & NA \\
\hline $\begin{array}{c}\text { Ataxia and } \\
\text { adult } \\
\text { neurodegenera } \\
\text { tive }\end{array}$ & $\begin{array}{l}\text { Androgen } \\
\text { Receptor;AR }\end{array}$ & $\begin{array}{l}\text { Spinal and bulbar } \\
\text { muscular atrophy } \\
\text { of Kennedy, } 313200\end{array}$ & 8 & $\begin{array}{c}\text { Hereditary } \\
\text { ataxia }\end{array}$ & $\mathrm{M}$ & $31-40$ & 39 & NA \\
\hline \begin{tabular}{|} 
Ataxia and \\
adult \\
neurodegenera \\
tive
\end{tabular} & $\begin{array}{l}\text { Androgen } \\
\text { Receptor;AR }\end{array}$ & $\begin{array}{l}\text { Spinal and bulbar } \\
\text { muscular atrophy } \\
\text { of Kennedy, } 313200\end{array}$ & 9 & $\begin{array}{l}\text { Amyotrophic } \\
\text { lateral } \\
\text { sclerosis or } \\
\text { motor neuron } \\
\text { disease }\end{array}$ & $\mathrm{M}$ & $51-60$ & 62 & NA \\
\hline
\end{tabular}




\begin{tabular}{|c|c|c|c|c|c|c|c|c|}
\hline $\begin{array}{c}\text { Ataxia and } \\
\text { adult } \\
\text { neurodegenera } \\
\text { tive }\end{array}$ & $\begin{array}{l}\text { Atrophin-1; } \\
\text { ATN1 }\end{array}$ & $\begin{array}{l}\text { Dentatorubral-palli } \\
\text { doluysian atrophy, } \\
125370\end{array}$ & 10 & $\begin{array}{c}\text { Hereditary } \\
\text { ataxia }\end{array}$ & $\mathrm{F}$ & $71-80$ & 57 & 17 \\
\hline $\begin{array}{c}\text { Ataxia and } \\
\text { adult } \\
\text { neurodegenera } \\
\text { tive }\end{array}$ & $\begin{array}{l}\text { Atrophin-1; } \\
\text { ATN1 }\end{array}$ & $\begin{array}{l}\text { Dentatorubral-palli } \\
\text { doluysian atrophy, } \\
125370\end{array}$ & 11 & $\begin{array}{c}\text { Hereditary } \\
\text { ataxia }\end{array}$ & $\mathrm{F}$ & $71-80$ & 52 & 18 \\
\hline $\begin{array}{l}\text { Ataxia and } \\
\text { adult } \\
\text { neurodegenera }\end{array}$ & $\begin{array}{l}\text { Ataxin-1; } \\
\text { ATXN1 }\end{array}$ & $\begin{array}{l}\text { Spinocerebellar } \\
\text { ataxia 1, } 164400\end{array}$ & 12 & $\begin{array}{c}\text { Hereditary } \\
\text { ataxia }\end{array}$ & $\mathrm{M}$ & $11-20$ & 44 & 15 \\
\hline $\begin{array}{c}\text { Ataxia and } \\
\text { adult } \\
\text { neurodegenera } \\
\text { tive }\end{array}$ & $\begin{array}{l}\text { Ataxin-2; } \\
\text { ATXN2 }\end{array}$ & $\begin{array}{l}\text { Spinocerebellar } \\
\text { ataxia } 2,183090\end{array}$ & 13 & $\begin{array}{l}\text { Early onset } \\
\text { and familial } \\
\text { Parkinson's } \\
\text { Disease }\end{array}$ & $\mathrm{M}$ & $61-70$ & 40 & 22 \\
\hline $\begin{array}{c}\text { Ataxia and } \\
\text { adult }\end{array}$ & $\begin{array}{l}\text { Ataxin-2; } \\
\text { ATXN2 }\end{array}$ & $\begin{array}{l}\text { Spinocerebellar } \\
\text { ataxia 2, } 183090\end{array}$ & 14 & $\begin{array}{c}\text { Hereditary } \\
\text { ataxia }\end{array}$ & $\mathrm{M}$ & $31-40$ & 42 & 22 \\
\hline
\end{tabular}




\begin{tabular}{|c|c|c|c|c|c|c|c|c|}
\hline $\begin{array}{c}\text { neurodegenera } \\
\text { tive }\end{array}$ & & & & & & & & \\
\hline $\begin{array}{c}\text { Ataxia and } \\
\text { adult } \\
\text { neurodegenera } \\
\text { tive }\end{array}$ & $\begin{array}{l}\text { Ataxin-2; } \\
\text { ATXN2 }\end{array}$ & $\begin{array}{l}\text { Spinocerebellar } \\
\text { ataxia 2, } 183090\end{array}$ & 15 & $\begin{array}{c}\text { Affected } \\
\text { mother of } 16\end{array}$ & $\mathrm{~F}$ & $61-70$ & 41 & 31 \\
\hline $\begin{array}{l}\text { Ataxia and } \\
\text { adult } \\
\text { neurodegenera } \\
\text { tive }\end{array}$ & $\begin{array}{l}\text { Ataxin-2; } \\
\text { ATXN2 }\end{array}$ & $\begin{array}{l}\text { Spinocerebellar } \\
\text { ataxia } 2,183090\end{array}$ & 16 & $\begin{array}{l}\text { Amyotrophic } \\
\text { lateral } \\
\text { sclerosis or } \\
\text { motor neuron } \\
\text { disease }\end{array}$ & $M$ & $31-40$ & 33 & 22 \\
\hline $\begin{array}{c}\text { Ataxia and } \\
\text { adult } \\
\text { neurodegenera } \\
\text { tive }\end{array}$ & $\begin{array}{l}\text { Ataxin-3; } \\
\text { ATXN3 }\end{array}$ & $\begin{array}{l}\text { Spinocerebellar } \\
\text { ataxia } 3,164400\end{array}$ & 17 & $\begin{array}{l}\text { Hereditary } \\
\text { ataxia }\end{array}$ & $M$ & $41-50$ & 73 & 29 \\
\hline $\begin{array}{c}\text { Ataxia and } \\
\text { adult } \\
\text { neurodegenera } \\
\text { tive }\end{array}$ & $\begin{array}{l}\text { Ataxin-3; } \\
\text { ATXN3 }\end{array}$ & $\begin{array}{l}\text { Spinocerebellar } \\
\text { ataxia } 3,164400\end{array}$ & 18 & $\begin{array}{l}\text { Complex } \\
\text { Parkinsonism } \\
\text { (includes } \\
\text { pallido-pyram }\end{array}$ & $M$ & $51-60$ & 64 & 28 \\
\hline
\end{tabular}




\begin{tabular}{|c|c|c|c|c|c|c|c|c|}
\hline & & & & $\begin{array}{c}\text { idal } \\
\text { syndromes) }\end{array}$ & & & & \\
\hline $\begin{array}{c}\text { Ataxia and } \\
\text { adult } \\
\text { neurodegenera } \\
\text { tive }\end{array}$ & $\begin{array}{l}\text { Ataxin-7; } \\
\text { ATXN7 }\end{array}$ & $\begin{array}{l}\text { Spinocerebellar } \\
\text { ataxia } 7,164500\end{array}$ & 19 & $\begin{array}{l}\text { Hereditary } \\
\text { ataxia }\end{array}$ & $\mathrm{F}$ & $61-70$ & 54 & 11 \\
\hline $\begin{array}{c}\text { Ataxia and } \\
\text { adult } \\
\text { neurodegenera } \\
\text { tive }\end{array}$ & $\begin{array}{l}\text { Calcium } \\
\text { channel, } \\
\text { voltage-dep } \\
\text { endent, p/q } \\
\text { type, } \\
\text { alpha-1a } \\
\text { subunit; } \\
\text { CACNA1A }\end{array}$ & $\begin{array}{l}\text { Spinocerebellar } \\
\text { ataxia 6, } 183086\end{array}$ & 20 & $\begin{array}{l}\text { Hereditary } \\
\text { ataxia }\end{array}$ & $\mathrm{F}$ & $51-60$ & 22 & 13 \\
\hline $\begin{array}{c}\text { Ataxia and } \\
\text { adult } \\
\text { neurodegenera } \\
\text { tive }\end{array}$ & $\begin{array}{l}\text { Calcium } \\
\text { channel, } \\
\text { voltage-dep } \\
\text { endent, p/q } \\
\text { type, } \\
\text { alpha-1a }\end{array}$ & $\begin{array}{l}\text { Spinocerebellar } \\
\text { ataxia 6, } 183086\end{array}$ & 21 & $\begin{array}{l}\text { Hereditary } \\
\text { ataxia }\end{array}$ & $\mathrm{F}$ & $51-60$ & 22 & 13 \\
\hline
\end{tabular}




\begin{tabular}{|c|c|c|c|c|c|c|c|c|}
\hline & $\begin{array}{l}\text { subunit; } \\
\text { CACNA1A }\end{array}$ & & & & & & & \\
\hline $\begin{array}{c}\text { Ataxia and } \\
\text { adult } \\
\text { neurodegenera } \\
\text { tive }\end{array}$ & $\begin{array}{l}\text { Chromosom } \\
\text { e } 9 \text { open } \\
\text { reading } \\
\text { frame } 72 ; \\
\text { c9orf72 }\end{array}$ & $\begin{array}{l}\text { Frontotemporal } \\
\text { dementia and/or } \\
\text { amyotrophic lateral } \\
\text { sclerosis, } 105550\end{array}$ & 22 & $\begin{array}{l}\text { Amyotrophic } \\
\text { lateral } \\
\text { sclerosis or } \\
\text { motor neuron } \\
\text { disease }\end{array}$ & $M$ & $71-80$ & 593 & 2 \\
\hline $\begin{array}{l}\text { Ataxia and } \\
\text { adult } \\
\text { neurodegenera } \\
\text { tive }\end{array}$ & $\begin{array}{l}\text { Chromosom } \\
\text { e } 9 \text { open } \\
\text { reading } \\
\text { frame } 72 ; \\
\text { c9orf72 }\end{array}$ & $\begin{array}{l}\text { Frontotemporal } \\
\text { dementia and/or } \\
\text { amyotrophic lateral } \\
\text { sclerosis, } 105550\end{array}$ & 23 & $\begin{array}{l}\text { Early onset } \\
\text { dementia }\end{array}$ & $\mathrm{F}$ & $71-80$ & 552 & 5 \\
\hline $\begin{array}{l}\text { Ataxia and } \\
\text { adult } \\
\text { neurodegenera } \\
\text { tive }\end{array}$ & $\begin{array}{l}\text { Chromosom } \\
\text { e } 9 \text { open } \\
\text { reading } \\
\text { frame } 72 ; \\
\text { c9orf72 }\end{array}$ & $\begin{array}{l}\text { Frontotemporal } \\
\text { dementia and/or } \\
\text { amyotrophic lateral } \\
\text { sclerosis, } 105550\end{array}$ & 24 & $\begin{array}{l}\text { Amyotrophic } \\
\text { lateral } \\
\text { sclerosis or } \\
\text { motor neuron } \\
\text { disease }\end{array}$ & $M$ & $71-80$ & 546 & 5 \\
\hline $\begin{array}{l}\text { Ataxia and } \\
\text { adult }\end{array}$ & $\begin{array}{l}\text { Chromosom } \\
\text { e } 9 \text { open } \\
\text { reading }\end{array}$ & $\begin{array}{l}\text { Frontotemporal } \\
\text { dementia and/or }\end{array}$ & 25 & $\begin{array}{l}\text { Amyotrophic } \\
\text { lateral } \\
\text { sclerosis or }\end{array}$ & $\mathrm{F}$ & $61-70$ & 411 & 2 \\
\hline
\end{tabular}




\begin{tabular}{|c|c|c|c|c|c|c|c|c|}
\hline $\begin{array}{c}\text { neurodegenera } \\
\text { tive }\end{array}$ & $\begin{array}{l}\text { frame 72; } \\
\text { C9orf72 }\end{array}$ & $\begin{array}{l}\text { amyotrophic lateral } \\
\text { sclerosis, } 105550\end{array}$ & & $\begin{array}{c}\text { motor neuron } \\
\text { disease }\end{array}$ & & & & \\
\hline $\begin{array}{c}\text { Ataxia and } \\
\text { adult } \\
\text { neurodegenera } \\
\text { tive }\end{array}$ & $\begin{array}{l}\text { Chromosom } \\
\text { e } 9 \text { open } \\
\text { reading } \\
\text { frame } 72 ; \\
\text { c9orf72 }\end{array}$ & $\begin{array}{l}\text { Frontotemporal } \\
\text { dementia and/or } \\
\text { amyotrophic lateral } \\
\text { sclerosis, } 105550\end{array}$ & 26 & $\begin{array}{l}\text { Early onset } \\
\text { dementia }\end{array}$ & $M$ & $81-90$ & 346 & 8 \\
\hline $\begin{array}{c}\text { Ataxia and } \\
\text { adult } \\
\text { neurodegenera } \\
\text { tive }\end{array}$ & $\begin{array}{l}\text { Chromosom } \\
\text { e } 9 \text { open } \\
\text { reading } \\
\text { frame } 72 ; \\
\text { c9orf72 }\end{array}$ & $\begin{array}{l}\text { Frontotemporal } \\
\text { dementia and/or } \\
\text { amyotrophic lateral } \\
\text { sclerosis, } 105550\end{array}$ & 27 & $\begin{array}{l}\text { Early onset } \\
\text { and familial } \\
\text { Parkinson's } \\
\text { Disease }\end{array}$ & $M$ & $31-40$ & 275 & 7 \\
\hline $\begin{array}{c}\text { Ataxia and } \\
\text { adult } \\
\text { neurodegenera } \\
\text { tive }\end{array}$ & $\begin{array}{l}\text { Chromosom } \\
\text { e } 9 \text { open } \\
\text { reading } \\
\text { frame } 72 ; \\
\text { c9orf72 }\end{array}$ & $\begin{array}{l}\text { Frontotemporal } \\
\text { dementia and/or } \\
\text { amyotrophic lateral } \\
\text { sclerosis, } 105550\end{array}$ & 28 & $\begin{array}{l}\text { Early onset } \\
\text { dementia }\end{array}$ & $\mathrm{M}$ & $41-50$ & 627 & 2 \\
\hline $\begin{array}{l}\text { Ataxia and } \\
\text { adult }\end{array}$ & $\begin{array}{l}\text { Frataxin; } \\
\text { FXN }\end{array}$ & $\begin{array}{l}\text { Friedreich ataxia, } \\
229300\end{array}$ & 29 & $\begin{array}{l}\text { Hereditary } \\
\text { ataxia }\end{array}$ & $M$ & $51-60$ & 79 & 108 \\
\hline
\end{tabular}




\begin{tabular}{|c|c|c|c|c|c|c|c|c|}
\hline $\begin{array}{c}\text { neurodegenera } \\
\text { tive }\end{array}$ & & & & & & & & \\
\hline $\begin{array}{c}\text { Ataxia and } \\
\text { adult } \\
\text { neurodegenera } \\
\text { tive }\end{array}$ & $\begin{array}{l}\text { Frataxin; } \\
\text { FXN }\end{array}$ & $\begin{array}{l}\text { Friedreich ataxia, } \\
229300\end{array}$ & 30 & $\begin{array}{l}\text { Hereditary } \\
\text { ataxia }\end{array}$ & $\mathrm{F}$ & $61-70$ & 139 & 93 \\
\hline $\begin{array}{c}\text { Ataxia and } \\
\text { adult } \\
\text { neurodegenera } \\
\text { tive }\end{array}$ & $\begin{array}{l}\text { Frataxin; } \\
\text { FXN }\end{array}$ & $\begin{array}{l}\text { Friedreich ataxia, } \\
229300\end{array}$ & 31 & $\begin{array}{c}\text { Hereditary } \\
\text { ataxia }\end{array}$ & $\mathrm{F}$ & $41-50$ & 118 & 83 \\
\hline $\begin{array}{c}\text { Ataxia and } \\
\text { adult } \\
\text { neurodegenera } \\
\text { tive }\end{array}$ & $\begin{array}{l}\text { Frataxin; } \\
\text { FXN }\end{array}$ & $\begin{array}{l}\text { Friedreich ataxia, } \\
229300\end{array}$ & 32 & $\begin{array}{l}\text { Hereditary } \\
\text { ataxia }\end{array}$ & $\mathrm{F}$ & $41-50$ & 101 & 75 \\
\hline $\begin{array}{c}\text { Ataxia and } \\
\text { adult } \\
\text { neurodegenera } \\
\text { tive }\end{array}$ & $\begin{array}{l}\text { Frataxin; } \\
\text { FXN }\end{array}$ & $\begin{array}{l}\text { Friedreich ataxia, } \\
229300\end{array}$ & 33 & $\begin{array}{l}\text { Ultra-rare } \\
\text { undescribed } \\
\text { monogenic } \\
\text { disorders }\end{array}$ & $\mathrm{M}$ & $31-40$ & 101 & 75 \\
\hline
\end{tabular}




\begin{tabular}{|c|c|c|c|c|c|c|c|c|}
\hline $\begin{array}{c}\text { Ataxia and } \\
\text { adult } \\
\text { neurodegenera } \\
\text { tive }\end{array}$ & $\begin{array}{l}\text { Huntingtin; } \\
\text { HTT }\end{array}$ & $\begin{array}{l}\text { Huntington disease, } \\
143100\end{array}$ & 34 & $\begin{array}{l}\text { Hereditary } \\
\text { ataxia }\end{array}$ & $\mathrm{F}$ & $51-60$ & 21 & 44 \\
\hline $\begin{array}{c}\text { Ataxia and } \\
\text { adult } \\
\text { neurodegenera } \\
\text { tive }\end{array}$ & $\begin{array}{c}\text { Huntingtin; } \\
\text { HTT }\end{array}$ & $\begin{array}{l}\text { Huntington disease, } \\
143100\end{array}$ & 35 & $\begin{array}{l}\text { Hereditary } \\
\text { spastic } \\
\text { paraplegia }\end{array}$ & $\mathrm{F}$ & $51-60$ & 21 & 56 \\
\hline $\begin{array}{c}\text { Ataxia and } \\
\text { adult } \\
\text { neurodegenera } \\
\text { tive }\end{array}$ & $\begin{array}{l}\text { Huntingtin; } \\
\text { HTT }\end{array}$ & $\begin{array}{l}\text { Huntington disease, } \\
143100\end{array}$ & 36 & $\begin{array}{l}\text { Complex } \\
\text { Parkinsonism } \\
\text { (includes } \\
\text { pallido-pyram } \\
\text { idal } \\
\text { syndromes) }\end{array}$ & $\mathrm{F}$ & $51-60$ & 52 & 21 \\
\hline $\begin{array}{c}\text { Ataxia and } \\
\text { adult } \\
\text { neurodegenera } \\
\text { tive }\end{array}$ & $\begin{array}{l}\text { Huntingtin; } \\
\text { HTT }\end{array}$ & $\begin{array}{l}\text { Huntington disease, } \\
143100\end{array}$ & 37 & $\begin{array}{l}\text { Hereditary } \\
\text { ataxia }\end{array}$ & $\mathrm{F}$ & $71-80$ & 44 & 17 \\
\hline
\end{tabular}




\begin{tabular}{|c|c|c|c|c|c|c|c|c|}
\hline $\begin{array}{c}\text { Ataxia and } \\
\text { adult } \\
\text { neurodegenera } \\
\text { tive }\end{array}$ & $\begin{array}{c}\text { Huntingtin; } \\
\text { HTT }\end{array}$ & $\begin{array}{l}\text { Huntington disease, } \\
143100\end{array}$ & 38 & $\begin{array}{l}\text { Hereditary } \\
\text { ataxia }\end{array}$ & $\mathrm{F}$ & $51-60$ & 43 & 19 \\
\hline $\begin{array}{c}\text { Ataxia and } \\
\text { adult } \\
\text { neurodegenera } \\
\text { tive }\end{array}$ & $\begin{array}{c}\text { Huntingtin; } \\
\text { HTT }\end{array}$ & $\begin{array}{c}\text { Huntington disease, } \\
143100\end{array}$ & 39 & $\begin{array}{l}\text { Hereditary } \\
\text { ataxia }\end{array}$ & $\mathrm{F}$ & $61-70$ & 42 & 17 \\
\hline $\begin{array}{c}\text { Ataxia and } \\
\text { adult } \\
\text { neurodegenera } \\
\text { tive }\end{array}$ & $\begin{array}{c}\text { Huntingtin; } \\
\text { HTT }\end{array}$ & $\begin{array}{c}\text { Huntington disease, } \\
143100\end{array}$ & 40 & $\begin{array}{l}\text { Ultra-rare } \\
\text { undescribed } \\
\text { monogenic } \\
\text { disorders }\end{array}$ & $\mathrm{F}$ & $61-70$ & 38 & 17 \\
\hline $\begin{array}{c}\text { Ataxia and } \\
\text { adult } \\
\text { neurodegenera } \\
\text { tive }\end{array}$ & $\begin{array}{l}\text { Huntingtin; } \\
\text { HTT }\end{array}$ & $\begin{array}{c}\text { Huntington disease, } \\
143100\end{array}$ & 41 & $\begin{array}{l}\text { Ultra-rare } \\
\text { undescribed } \\
\text { monogenic } \\
\text { disorders }\end{array}$ & $\mathrm{F}$ & $61-70$ & 38 & 17 \\
\hline $\begin{array}{l}\text { Ataxia and } \\
\text { adult }\end{array}$ & $\begin{array}{l}\text { tata } \\
\text { box-binding } \\
\text { protein; TBP }\end{array}$ & $\begin{array}{l}\text { Spinocerebellar } \\
\text { ataxia } 17,607136\end{array}$ & 42 & $\begin{array}{l}\text { Hereditary } \\
\text { ataxia }\end{array}$ & $\mathrm{F}$ & $61-70$ & 58 & 36 \\
\hline
\end{tabular}




\begin{tabular}{|c|c|c|c|c|c|c|c|c|}
\hline $\begin{array}{c}\text { neurodegenera } \\
\text { tive }\end{array}$ & & & & & & & & \\
\hline $\begin{array}{c}\text { Ataxia and } \\
\text { adult } \\
\text { neurodegenera } \\
\text { tive }\end{array}$ & $\begin{array}{c}\text { tata } \\
\text { box-binding } \\
\text { protein; TBP }\end{array}$ & $\begin{array}{l}\text { Spinocerebellar } \\
\text { ataxia 17, } 607136\end{array}$ & 43 & $\begin{array}{c}\text { Hereditary } \\
\text { ataxia }\end{array}$ & $\mathrm{F}$ & $51-60$ & 52 & 38 \\
\hline Complex ID & $\begin{array}{l}\text { Ataxin-2; } \\
\text { ATXN2 }\end{array}$ & $\begin{array}{l}\text { Spinocerebellar } \\
\text { ataxia 2, } 183090\end{array}$ & 44 & $\begin{array}{l}\text { Intellectual } \\
\text { disability }\end{array}$ & $\mathrm{F}$ & $1-10$ & 99 & 22 \\
\hline Complex ID & $\begin{array}{l}\text { Ataxin-2; } \\
\text { ATXN2 }\end{array}$ & $\begin{array}{l}\text { Spinocerebellar } \\
\text { ataxia } 2,183090\end{array}$ & 45 & Father of 48 & $\mathrm{M}$ & $31-40$ & 22 & 41 \\
\hline Complex ID & $\begin{array}{l}\text { Ataxin-7; } \\
\text { ATXN7 }\end{array}$ & $\begin{array}{l}\text { Spinocerebellar } \\
\text { ataxia 7, } 164500\end{array}$ & 46 & $\begin{array}{l}\text { Intellectual } \\
\text { disability }\end{array}$ & $\mathrm{F}$ & $1-10$ & 118 & 12 \\
\hline Complex ID & $\begin{array}{l}\text { Ataxin-7; } \\
\text { ATXN7 }\end{array}$ & $\begin{array}{l}\text { Spinocerebellar } \\
\text { ataxia 7, } 164500\end{array}$ & 47 & $\begin{array}{c}\text { Mitochondrial } \\
\text { disorders }\end{array}$ & $\mathrm{F}$ & $1-10$ & 95 & 10 \\
\hline Complex ID & $\begin{array}{c}\text { Atrophin-1; } \\
\text { ATN1 }\end{array}$ & $\begin{array}{l}\text { Dentatorubral-palli } \\
\text { doluysian atrophy, } \\
125370\end{array}$ & 48 & $\begin{array}{l}\text { Early onset } \\
\text { dementia }\end{array}$ & $\mathrm{M}$ & $11-20$ & 81 & 15 \\
\hline
\end{tabular}




\begin{tabular}{|c|c|c|c|c|c|c|c|c|}
\hline Complex ID & $\begin{array}{l}\text { Atrophin-1; } \\
\qquad \text { ATN1 }\end{array}$ & $\begin{array}{l}\text { Dentatorubral-palli } \\
\text { doluysian atrophy, } \\
125370\end{array}$ & 49 & $\begin{array}{l}\text { Intellectual } \\
\text { disability }\end{array}$ & $\mathrm{F}$ & $11-20$ & 69 & 12 \\
\hline Complex ID & $\begin{array}{l}\text { Atrophin-1; } \\
\text { ATN1 }\end{array}$ & $\begin{array}{l}\text { Dentatorubral-palli } \\
\text { doluysian atrophy, } \\
125370\end{array}$ & 50 & father of 44 & $\mathrm{M}$ & $41-50$ & 64 & 17 \\
\hline Complex ID & $\begin{array}{l}\text { Huntingtin; } \\
\text { HTT }\end{array}$ & $\begin{array}{l}\text { Huntington disease, } \\
143100\end{array}$ & 51 & $\begin{array}{l}\text { Mitochondrial } \\
\text { disorders }\end{array}$ & $\mathrm{F}$ & $1-10$ & 99 & 21 \\
\hline Complex ID & $\begin{array}{l}\text { Huntingtin; } \\
\text { HTT }\end{array}$ & $\begin{array}{l}\text { Huntington disease, } \\
143100\end{array}$ & 52 & $\begin{array}{l}\text { Early onset } \\
\text { dystonia }\end{array}$ & $\mathrm{M}$ & $11-20$ & 93 & 17 \\
\hline $\begin{array}{l}\text { Intellectual } \\
\text { disability and } \\
\text { neuromuscular }\end{array}$ & $\begin{array}{c}\text { Dystrophia } \\
\text { myotonica } \\
\text { protein } \\
\text { kinase; } \\
\text { DMPK }\end{array}$ & $\begin{array}{c}\text { Myotonic } \\
\text { dystrophy 1, } \\
160900\end{array}$ & 53 & $\begin{array}{c}\text { Distal } \\
\text { Myopathies }\end{array}$ & $\mathrm{F}$ & $21-30$ & 129 & 13 \\
\hline $\begin{array}{l}\text { Intellectual } \\
\text { disability and } \\
\text { neuromuscular }\end{array}$ & $\begin{array}{l}\text { Dystrophia } \\
\text { myotonica } \\
\text { protein }\end{array}$ & $\begin{array}{c}\text { Myotonic } \\
\text { dystrophy 1, } \\
160901\end{array}$ & 54 & $\begin{array}{c}\text { Distal } \\
\text { Myopathies }\end{array}$ & $\mathrm{M}$ & $41-50$ & 106 & 13 \\
\hline
\end{tabular}




\begin{tabular}{|c|c|c|c|c|c|c|c|c|}
\hline & $\begin{array}{l}\text { kinase; } \\
\text { DMPK }\end{array}$ & & & & & & & \\
\hline $\begin{array}{l}\text { Intellectual } \\
\text { disability and } \\
\text { neuromuscular }\end{array}$ & $\begin{array}{c}\text { Dystrophia } \\
\text { myotonica } \\
\text { protein } \\
\text { kinase; } \\
\text { DMPK }\end{array}$ & $\begin{array}{c}\text { Myotonic } \\
\text { dystrophy 1, } \\
160902\end{array}$ & 55 & $\begin{array}{l}\text { Congenital } \\
\text { myopathy }\end{array}$ & $\mathrm{M}$ & $41-50$ & 117 & 13 \\
\hline $\begin{array}{l}\text { Intellectual } \\
\text { disability and } \\
\text { neuromuscular }\end{array}$ & $\begin{array}{c}\text { Dystrophia } \\
\text { myotonica } \\
\text { protein } \\
\text { kinase; } \\
\text { DMPK }\end{array}$ & $\begin{array}{c}\text { Myotonic } \\
\text { dystrophy 1, } \\
160903\end{array}$ & 56 & $\begin{array}{l}\text { Congenital } \\
\text { muscular } \\
\text { dystrophy }\end{array}$ & $F$ & $41-50$ & 116 & 5 \\
\hline $\begin{array}{l}\text { Intellectual } \\
\text { disability and } \\
\text { neuromuscular }\end{array}$ & $\begin{array}{c}\text { Dystrophia } \\
\text { myotonica } \\
\text { protein } \\
\text { kinase; } \\
\text { DMPK }\end{array}$ & $\begin{array}{c}\text { Myotonic } \\
\text { dystrophy 1, } \\
160904\end{array}$ & 57 & $\begin{array}{l}\text { Congenital } \\
\text { muscular } \\
\text { dystrophy }\end{array}$ & $F$ & $11-20$ & 107 & 10 \\
\hline
\end{tabular}




\begin{tabular}{|c|c|c|c|c|c|c|c|c|}
\hline $\begin{array}{l}\text { Intellectual } \\
\text { disability and } \\
\text { neuromuscular }\end{array}$ & $\begin{array}{c}\text { Dystrophia } \\
\text { myotonica } \\
\text { protein } \\
\text { kinase; } \\
\text { DMPK }\end{array}$ & $\begin{array}{c}\text { Myotonic } \\
\text { dystrophy 1, } \\
160905\end{array}$ & 58 & $\begin{array}{c}\text { Hereditary } \\
\text { ataxia }\end{array}$ & $\mathrm{F}$ & $61-70$ & 112 & 16 \\
\hline $\begin{array}{l}\text { Intellectual } \\
\text { disability and } \\
\text { neuromuscular }\end{array}$ & $\begin{array}{c}\text { Dystrophia } \\
\text { myotonica } \\
\text { protein } \\
\text { kinase; } \\
\text { DMPK }\end{array}$ & $\begin{array}{c}\text { Myotonic } \\
\text { dystrophy 1, } \\
160906\end{array}$ & 59 & $\begin{array}{l}\text { Intellectual } \\
\text { disability }\end{array}$ & $\mathrm{F}$ & $1-10$ & 102 & 12 \\
\hline $\begin{array}{l}\text { Intellectual } \\
\text { disability }\end{array}$ & $\begin{array}{c}\text { Fragile X } \\
\text { syndrome, } \\
300624\end{array}$ & $\begin{array}{c}\text { FMRP } \\
\text { translational } \\
\text { regulator; FMR1 }\end{array}$ & 60 & $\begin{array}{l}\text { Intellectual } \\
\text { disability }\end{array}$ & $\mathrm{M}$ & $1-10$ & 172 & NA \\
\hline $\begin{array}{l}\text { Intellectual } \\
\text { disability }\end{array}$ & $\begin{array}{l}\text { Fragile X } \\
\text { syndrome, } \\
300624\end{array}$ & $\begin{array}{c}\text { FMRP } \\
\text { translational } \\
\text { regulator; FMR1 }\end{array}$ & 61 & $\begin{array}{l}\text { Intellectual } \\
\text { disability }\end{array}$ & $\mathrm{M}$ & $1-10$ & 179 & NA \\
\hline
\end{tabular}




\begin{tabular}{|c|c|c|c|c|c|c|c|c|}
\hline $\begin{array}{l}\text { Intellectual } \\
\text { disability }\end{array}$ & $\begin{array}{l}\text { Fragile X } \\
\text { syndrome, } \\
300624\end{array}$ & $\begin{array}{c}\text { FMRP } \\
\text { translational } \\
\text { regulator; FMR1 }\end{array}$ & 62 & $\begin{array}{l}\text { Intellectual } \\
\text { disability }\end{array}$ & $\mathrm{M}$ & $11-20$ & 170 & NA \\
\hline $\begin{array}{l}\text { Intellectual } \\
\text { disability }\end{array}$ & $\begin{array}{l}\text { Fragile X } \\
\text { syndrome, } \\
300624\end{array}$ & $\begin{array}{c}\text { FMRP } \\
\text { translational } \\
\text { regulator; FMR1 }\end{array}$ & 63 & $\begin{array}{l}\text { Intellectual } \\
\text { disability }\end{array}$ & $\mathrm{M}$ & $1-10$ & 148 & NA \\
\hline $\begin{array}{l}\text { Intellectual } \\
\text { disability }\end{array}$ & $\begin{array}{l}\text { Fragile X } \\
\text { syndrome, } \\
300624\end{array}$ & $\begin{array}{c}\text { FMRP } \\
\text { translational } \\
\text { regulator; FMR1 }\end{array}$ & 64 & $\begin{array}{l}\text { Intellectual } \\
\text { disability }\end{array}$ & $\mathrm{M}$ & $11-20$ & 97 & NA \\
\hline $\begin{array}{l}\text { Intellectual } \\
\text { disability }\end{array}$ & $\begin{array}{l}\text { Fragile X } \\
\text { syndrome, } \\
300624\end{array}$ & $\begin{array}{c}\text { FMRP } \\
\text { translational } \\
\text { regulator; FMR1 }\end{array}$ & 65 & $\begin{array}{l}\text { Intellectual } \\
\text { disability }\end{array}$ & $\mathrm{M}$ & $1-10$ & 194 & NA \\
\hline $\begin{array}{l}\text { Intellectual } \\
\text { disability }\end{array}$ & $\begin{array}{l}\text { Fragile X } \\
\text { syndrome, } \\
300624\end{array}$ & $\begin{array}{c}\text { FMRP } \\
\text { translational } \\
\text { regulator; FMR1 }\end{array}$ & 66 & $\begin{array}{l}\text { Intellectual } \\
\text { disability }\end{array}$ & $\mathrm{M}$ & $1-10$ & 115 & $\mathrm{NA}$ \\
\hline
\end{tabular}




\begin{tabular}{|c|c|c|c|c|c|c|c|c|}
\hline $\begin{array}{l}\text { Intellectual } \\
\text { disability }\end{array}$ & $\begin{array}{l}\text { Fragile X } \\
\text { syndrome, } \\
300624\end{array}$ & $\begin{array}{c}\text { FMRP } \\
\text { translational } \\
\text { regulator; FMR1 }\end{array}$ & 67 & $\begin{array}{l}\text { Intellectual } \\
\text { disability }\end{array}$ & $\mathrm{M}$ & $1-10$ & 182 & NA \\
\hline $\begin{array}{l}\text { Intellectual } \\
\text { disability }\end{array}$ & $\begin{array}{l}\text { Fragile } X \\
\text { syndrome, } \\
300624\end{array}$ & $\begin{array}{c}\text { FMRP } \\
\text { translational } \\
\text { regulator; FMR1 }\end{array}$ & 68 & $\begin{array}{l}\text { Intellectual } \\
\text { disability }\end{array}$ & $\mathrm{M}$ & $1-10$ & 114 & NA \\
\hline $\begin{array}{l}\text { Intellectual } \\
\text { disability }\end{array}$ & $\begin{array}{l}\text { Fragile X } \\
\text { syndrome, } \\
300624\end{array}$ & $\begin{array}{c}\text { FMRP } \\
\text { translational } \\
\text { regulator; FMR1 }\end{array}$ & 69 & $\begin{array}{l}\text { Intellectual } \\
\text { disability }\end{array}$ & $\mathrm{F}$ & $11-20$ & 30 & 146 \\
\hline
\end{tabular}


Rxiv preprint doi: https://doi.org/10.1101/2020.11.06.371716; this version posted November 6, 2020. The copyright holder for this pr (which was not certified by peer review) is the author/funder. All rights reserved. No reuse allowed without permission.

Expansion Detection Performance Assessment
Clinical Samples
PCR Allele Analysis
WGS Expansion Detection
WGS Performance vs PCR

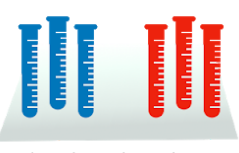

AR | ATN1 | ATXN1 | ATXN2 | ATXN3 FXN | FMR1 | HTT| TBP
TRP

\section{Expansion Detection In Individuals With Disease}

Clinical Report

PCR Allele Analysis

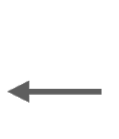

WGS Expansion Detection

Affected Individuals 


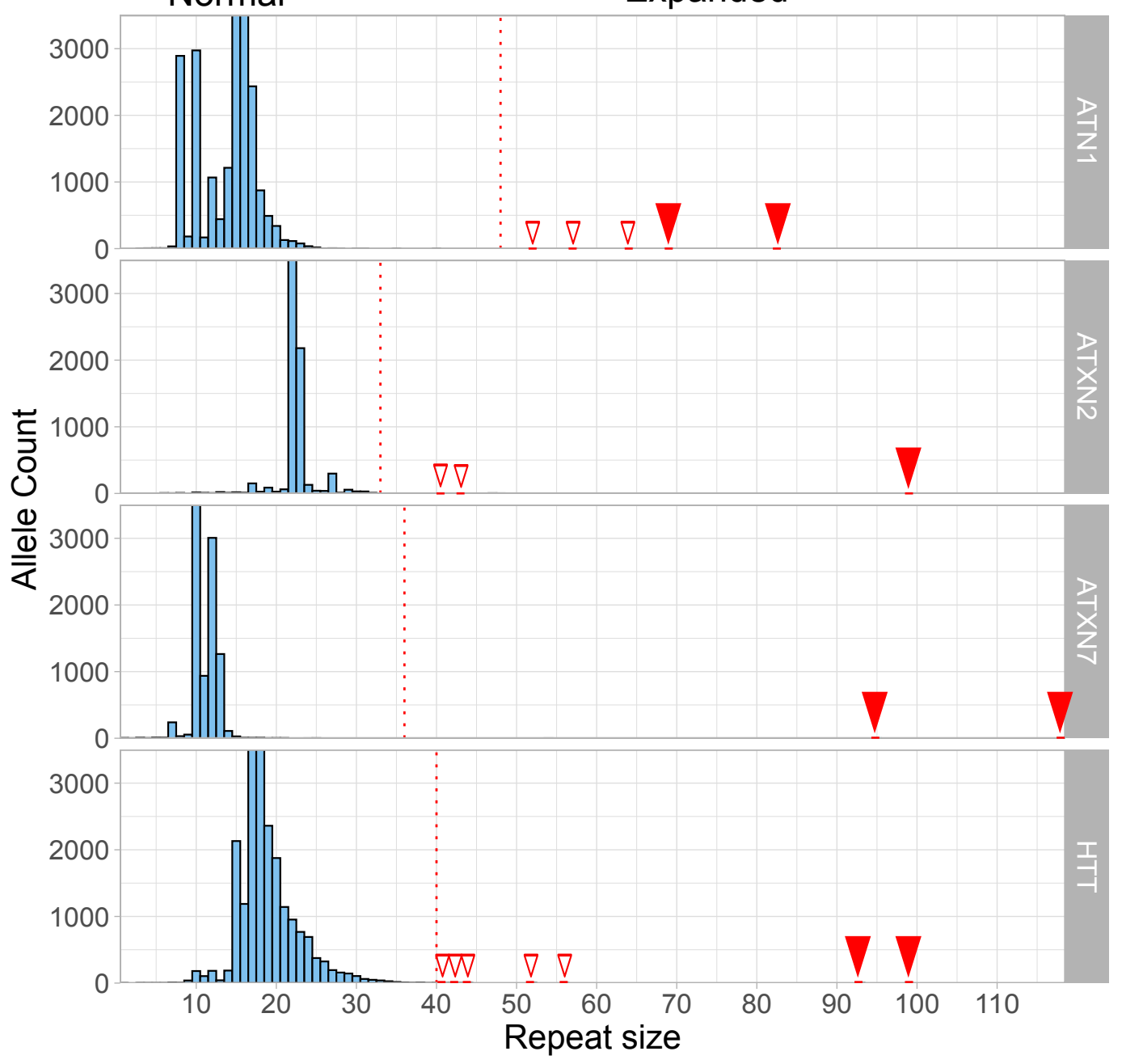

